First Peoples Child \& Family Review

A Journal on Innovation and Best Practices in Aboriginal Child Welfare Administration,

Research, Policy \& Practice

\title{
Editorial:The Legacy of a Child: Jordan's Principle
}

\section{Christine Wekerle, Marlyn Bennett and Don Fuchs}

Volume 4, Number 1, 2009

URI: https://id.erudit.org/iderudit/1069342ar

DOI: https://doi.org/10.7202/1069342ar

See table of contents

Publisher(s)

First Nations Child and Family Caring Society of Canada

ISSN

1708-489X (print)

2293-6610 (digital)

Explore this journal

Cite this document

Wekerle, C., Bennett, M. \& Fuchs, D. (2009). Editorial:The Legacy of a Child:

Jordan's Principle. First Peoples Child \& Family Review, 4(1), 5-7.

https://doi.org/10.7202/1069342ar viewed online.

https://apropos.erudit.org/en/users/policy-on-use/ 


\title{
Editorial: The Legacy of a Child: Jordan's Principle
}

\author{
Christine Wekerle, Marlyn Bennett and Don Fuchs
}

It has been said that a child shall lead the way. There are lessons to be learned from the smallest among us (Koptie \& Wesley-Esquimaux, this issue). The learning from a child's experience was a repeated key message at the "Caring Across the Boundaries" (CAB) conference held in Manitoba in late May 2009 (presentational material available on the web at: [http://www.fncaringsociety.org/ cab-conference/). The CAB conference and the majority of the articles that appear in this issue of the journal were initiated by the story of a toddler named Jordan (see Blackstock, 2008). Honoring the memory of Jordan was key to kicking off the $\mathrm{CAB}$ conference because through his experience we learned the price that many First Nations children pay ... unlike other other Canadian children born with complex medical needs, Jordan died before his needs could be addressed. Why? Because he was born to a First Nations family residing in a First Nation community! Jordan was an average child in some ways - loving teddy bears; yet, he was an extraordinary child in other ways - his little self incited a cry for social justice and ignited a posthumous movement to uphold human rights for all First Nations children through the creation of a child first principle called "Jordan's Principle” (Blackstock, 2008).

Jordan's Principle decrees that where a jurisdictional dispute arises between two government parties (provincial/ territorial or federal) or between two departments or ministries of the same government regarding payment for any services to a Status Indian child which are otherwise available to other Canadian children, the government or ministry/department of first contact must pay for the services without delay or disruption. The paying government party can then refer the matter to jurisdictional dispute mechanisms. In this way, the needs of the child get met first while still allowing for the jurisdictional dispute to be resolved later (First Nations Child \& Family Caring Society of Canada, 2007) (See background story at: http:// www.fncaringsociety.org/more/jordansPrinciple).
Sadly, the reality is that Jordan's story is not unique among First Peoples' communities. Presentations made at the $\mathrm{CAB}$ conference clearly and poignantly pointed to data that reflected on the reality of the economics of being ia child in need on reserve versus off-reserve. These presentations as well as focused on the overlap between the special needs of children and parental efforts at coping (Badry, this issue). Fort instance, children with FASD represent over $17 \%$ of all children in Care and 34\% of all children with disabilities in care. First Nations children are significantly overrepresented in this group (Fuchs, Burnside, Marchenski \& Mudry, 2007). These numbers are continuing to increase. Badry's article identifies the need for an additional range of cross disciplinary supports for children with FASD and their foster families. New standards for practice which provide more culturally appropriate service contacts have been shown to provide significant benefits for increasing the effective development outcomes for children with FASD in care and their foster families (Fuchs, 2008; Badry, this issue). The pressing issue is timely access to resources with jurisdictional delays that sees documents signed-off by too many governmental and service officials in a queue of so many documents and processes over days and months and years that count so dearly in a young life.

In the present issue, it is fitting to have the lead article written from a first-person perspective on First Peoples' maltreatment in terms of attachment disruption and traumatic separation from parents, siblings, extended family, community and cultural traditions (Montgomery-Reid, this issue). Trauma is compounded by prolonged emotional abuse in terms of verbal assaults on the child and isolation from caring adults and physical mistreatment for a child's natural behaviors. While child welfare is acknowledged as a protection system - and child safety is the foundation upon which normative child development proceeds - systeminvolved families have not been clearly evaluated in terms of trauma-based mental health and relationship issues 


\section{Editorial}

(Twigg \& Hengen; Blackstock; Badry; Koptie \& WesleyEsquimaux, this issue). Post-traumatic stress disorder symptomatology reflects physical, psychological and physiological responses that include reactivity to intrusive components in the environment (i.e., a startle response to sudden, loud noise; an anticipatory fear-based response to maltreatment-similar situations, such as being physically close to someone, being consciously aware in the present moment; the ability to self-soothe in stress situations; the ability to self-protect and protect others in perceived danger situations; trauma event-related fears such as feeling trapped; losing control, being harmed, death etc.; see APA, 2004 for diagnostic criteria). However, developmental traumatology theory puts forward that disorder is not necessary to have trauma-related negative effects. An elevated stress response, which has to fatigue in some time periods and may appear as depression or the need to self-medicate or self-distract from responding to on-going stress, is itself, related to brain structural, functioning and perceptual alterations (e.g., DeBellis, 2001; Glaser, 2000). In connecting trauma to poor outcomes, the intervention is indicated: directly address the trauma symptomatology and the conceptualization of trauma's impact on development.

A trauma model is valid in explaining the unique impact of emotional abuse (beyond the effect of physical abuse, sexual abuse, and neglect) in predicting adolescent dating violence (Wekerle et al., in press). A trauma model has explained alcohol abuse among adults (Whiffen \& MacIntosh, 2005), adolescent depression and suicidal ideation (e.g., Mazza \& Reynolds, 1999), adolescent substance abuse (e.g., Tonmyr, Jack, Brooks, Kennedy Dudding., this issue) and Aboriginal youth substance abuse (Stewart et al., 2009). The maltreatment - Post-Traumatic Stress Disorder - negative outcome has been examined most among females and with respect to sexual abuse history (e.g., Havig, 2008). However, the maltreatment and the context within which the maltreatment occurred need to be considered (Zielinski \& Bradshaw, 2006), particularly given the wide ranging impacts from migraine and chronic pain to gastrointestinal issues to mental health concerns and the evidence for efficacious prevention (e.g., MacMillan et al., in press). One key context remains poverty (LaFrance, this issue). More model programs and research on their effectiveness within the Aboriginal context are needed (Twigg \& Hengen; Wortzmann; Badry, this issue). The plea for help is echoed by Harding's poem on maltreatment's sometimes unseen and unheard impact (this issue). The need for social work practice - and all clinical services - to evaluate harm, as well as health promotion or positive intervention outcomes is underscored by Blackstock (this issue). There is a need to utilize the research information that currently exists towards planning in ways that minimize the likelihood of harm (Tonmyr, Jack, Brooks, Kennedy, \& Dudding, this issue). A community investment in research that focuses on similar concerns increases the likelihood that the research questions are formed with cultural competence (Twigg \& Hengen; Stewart, this issue), and that the data collected is more relevant to practice and innovation oriented. With increasing scholarly and experiential attention and reflection (Stewart; Koptie \& Wesley-Esquimaux, this issue), a way towards innovations in best practices and the knowledge translation of research to practice can be facilitated. In particular, success in having synchronization between evidence-based best practices and wise practices may ensue and answer the question: Does this way, this path, have a heart? (LaFrance, this issue).

\section{References:}

American Psychiatric Association. (2000). Diagnostic and statistical manual of mental disorders (4th edition - Rev. ed.). Washington, DC: American Psychiatric Association.

Badry, D. (this issue)

Blackstock, C. (this issue)

Blackstock, C. (2008). Reconciliation means not saying sorry twice: Lessons from child welfare in Canada. In From Truth to Reconciliation: Transforming the Legacy of Residential Schools, prepared for the Aboriginal Healing Foundation by M. Brant Castellano, L. Archibald and Mike DeGagne. Ottawa, ON: Aboriginal Healing Foundation.

DeBellis, M. D. (2001). Developmental traumatology: The psychobiological development of maltreated children and its implications for research, treatment, and policy. Development and Psychopathology, 13(3), 539-564.

First Nation Child \& Family Caring Society. (2007). Joint Declaration of support for Jordan's principle: To resolving jurisdictional disputes affecting services to First Nation children. Retrieved March 1, 2009, from http://www. fncaringsociety.org/docs/joint_declaration.pdf.

Fuchs, D., Burnside, L., Marchenski, S., \& Mudry, A. (2007). Children with FASD involved with the Manitoba child welfare system. Available: http://www.cecw-cepb.ca.

Fuchs, D. (2008). Children in care with FASD. Presentation at the Caring Across the Boundaries: Bridging Knowledge Gaps, Services and Policies to Support Fist Peoples Child Welfare and Health Conference, May 28-30, 2008, Winnipeg, Manitoba.

Glaser, D. (2000). Child abuse and neglect and the brain-A review. Journal of Child Psychology and Psychiatry and Allied Disciplines, 41, 97-118.

Harding, L. (this issue)

Havig, K. (2008). The health care experience of adult survivors of child sexual abuse.Trauma, Violence \& Abuse, 9, 19-33.

Lafrance, J. (this issue)

Kopti, S. and C. Wesley-Esquimaux. (this issue)

Macmillan, H.L., Wathen, C.N., Barlow, J., Fergusson, D.M., Leventhal, J. M. \& Taussig, H. N. (2009). Interventions 


\section{First Peoples Child \& Family Review, Volume 4, Number 1, 2009}

to prevent child maltreatment and associated impairment. Lancet, 2009, Jan 17; 373(9659): 250-66.

Mazza, J.J., \& Reynolds, W. M. (1999). Exposure to violence in young inner-city adolescents : Relationships with depression, suicidal ideation, and PTSD symptomatology. Journal of Abnormal Psychology, 27, 203-213.

Montgomery, J. (this issue)

Tonmyr, L. Jack, Brooks, B. Kennedy and P. Dudding (this issue).

Twigg and Hengen (this issue)

Stewart, S. (this issue).

Wekerle, C., Chen, M., Leung, E., Waechter, R., \& The MAP Research Team (in press). The Maltreatment and Adolescent Pathways (MAP) Project: A community action health research project on child protective services-involved teens. In N. Trocmé, S. Léveillé, I. Brown and C. Chamberland (Eds). Research-Community Partnerships in Child Welfare. Montreal: Mc-Gill-Queen's University Press.

Whiffen, V. \& MacIntosh, H. (2005). Mediators of the link between childhood sexual abuse and emotional distress. Trauma, Violence \& Abuse, 6, 24-39.

Wortzman, R. (this issue)

Zielinksi, D.S. \& Bradshaw, C.P. (2006). Ecological influences on the sequelae of child maltreatment: A review of the literature. Child Maltreatment, 11, 49-62. 